\title{
Purification of a Galactolipase from Rice Bran by Affinity Chromatography on Palmitoylated Gauze
}

\author{
Hideyuki Matsuda and Osamu Hirayama \\ Department of Agricultural Chemistry, Shimane University, Matsue 690, Japan
}

Received June 30, 1978

\begin{abstract}
Galactolipase (galactolipid acyl hydrolase, EC 3.1.1.26) was purified 147-fold in good yield $(91 \%$ ) from rice bran by affinity chromatography, in which the enzyme was adsorbed on a palmitoylated gauze column at $\mathrm{pH} 5.5$ and then was eluted with a buffer solution containing a detergent such as sodium deoxycholate or Triton $\mathrm{X}-100$ at $\mathrm{pH} 8.0$. The preparation obtained was further purified by gel filtration on a Sephadex G-100 column and isoelectric focusing. After electrophoresis, the enzyme separated into four components with different isoelectric points. It seems that galactolipase in rice bran exists in multiple forms. The major component (G-2) with isoelectric point of 7.3, one of them, was purified 268 -fold and electrophoretically homogeneous. The enzyme (G-2) hydrolyzed rapidly galactolipid and also slowly phospholipid, but hardly triglyceride.
\end{abstract}

Galactolipase (EC 3.1.1.26) catalyzes the hydrolysis of fatty acid ester bonds of galactolipids. Since the enzyme was first detected in the extract of Phaseolus multifloris primary leaves by Sastry and Kates, ${ }^{1)}$ the enzymes in several higher plants such as spinach leaves, ${ }^{2 !}$ bean primary leaves, ${ }^{3,4}$ and potato tubers ${ }^{5,6}$ have been purified and characterized. Especially, the galactolipase of potato tubers has been examined in detail. For example, the authors reported that the enzyme which was purified from potato tubers to homogeneity clearly exhibited the hydrolyzing activities for both galacto- and phospholipids. ${ }^{6}$ Galliard has proposed that these lipolytic acyl-hydrolases occuring in plants should be classified as non-specific acyl-hydrolase. ${ }^{\text {) }}$

The authors also reported that galactolipases exist in rice bran and the enzymes together with lipase play significant roles in the lipid degradation during the storage of rice grains. ${ }^{8,9}$ During the investigation, it was presumed that the rice bran galactolipase hydrolyzes not only galactolipids but also phospholipids as the potato enzyme mentioned above does.

On the other hand, rapid and effective methods for purification of galactolipase have been desired to investigate properties and physiological roles of the enzyme. Rock et al., ${ }^{10}$
Verine et al., ${ }^{11)}$ and Lairon et al. ${ }^{12}$ reported affinity chromatographies on agarose derivatives of phospholipase, adipose tissue lipase and pancreatic lipase, respectively. Recently, Horiuti et $a l .^{13)}$ described affinity chromatography on palmitoylated gauze of microbial lipase. However, with respect to galactolipase, no such report has apparently been published up to date.

The present paper describes the effective purification of a galactolipase from rice bran by means of affinity chromatography on palmitoylated gauze, gel filtration, and isoelectric focusing. The final preparation appeared to be homogeneous electrophoretically and had an isoelectric point of 7.3.

\section{MATERIALS AND METHODS}

Plant material. Rice bran used throughout this study was prepared from grains of "Koshihikari," one of Japonica varieties, produced in a Central Agricultural Experiment Station of Shimane Prefecture in 1976.

Substrates. Monogalactosyldiacylglycerol was prepared from spinach leaf lipids. ${ }^{14)}$ Phosphatidylcholine was purified from egg lipids. ${ }^{15)}$ Triacylglycerol was prepared from olive oil. ${ }^{18)}$

Reagents. Carrier ampholyte was obtained from LKB-Produktor AB, Sweden. Sephadex G-100 was 
purchased from Pharmacia Fine Chemicals $A B$, Sweden. All other reagents used were of analytical grade.

Enzyme assay. Enzyme was assayed by determining free fatty acid released from a substrate, spinach monogalactosyldiacylglycerol, according to the method reported previously. ${ }^{2,17}$ ) The assay system contained the following components in a total volume of $1.0 \mathrm{ml}$ : $0.1 \mathrm{ml}$ of the miceller substrate solution $(5 \mathrm{~mm}$ substrate, $10 \mathrm{~mm}$ sodium deoxycholate) which was dispersed by ultrasonic treatment, $0.2 \mathrm{ml}$ of $0.5 \mathrm{M}$ Tris$\mathrm{HCl}$ buffer ( $\mathrm{pH} 7.5$ ), $0.1 \mathrm{ml}$ of enzyme preparation and $0.6 \mathrm{ml}$ of water. The enzyme activity was expressed as enzyme unit, where one unit of enzyme is defined as the amount of the enzyme that releases one $\mu \mathrm{mol}$ of free fatty acid from the substrate per minute. The specific activity was expressed as the enzyme unit per $\mathrm{mg}$ of enzyme protein. Protein was determined by the Lowry method modified by Hartree. ${ }^{18)}$

Preparation of palmitoylated gauze. Palmitoylated gauze was prepared from well-dried and -defatted gauze by the method of Horiuti et $a l^{13}$ ) The amount of palmitoyl groups in the prepared palmitoylated gauze was determined to be about $2.4 \mathrm{mmol} / \mathrm{g}$ by using the rhodamine method as described previously. ${ }^{17}$ )

Gel filtration. A Sephadex G-100 column $(3 \times$ $40 \mathrm{~cm}$ ) equilibrated with $5 \mathrm{~mm}$ phosphate buffer $(\mathrm{pH} 8.0)$ was used, and applied proteins were eluted with the same buffer as described previously. ${ }^{9)}$

Isoelectric focusing. Isoelectric focusing was carried out in the $110 \mathrm{ml}$-apparatus of LKB, using a carrier ampholyte (the pH range of $3.5 \sim 10$ ) at a final concentration of $0.5 \%$ and a stepwise sucrose gradient $(0 \sim$ $50 \%)^{B)}$ Electrophoresis was performed at $900 \mathrm{~V}$ for $48 \mathrm{hr}$ at $4^{\circ} \mathrm{C}$. After electrophoresis, the contents of the column were fractionated into $3 \mathrm{ml}$ portions. Each portion was subjected to the measurements of $\mathrm{pH}$, optical density at $280 \mathrm{~nm}$, and the enzymic activity.

Polyacrylamide gel disc electrophoresis. Disc gel electrophoresis was carried out on polyacrylamide gels (7.0\% acrylamide, pH 9.0) based on the method described by Ornstein ${ }^{13)}$ and Davis. ${ }^{20)}$ Protein was detected by staining the gel with $1 \%$ amido black $10 \mathrm{~B}$ in $7 \%$ acetic acid.

\section{RESULTS}

Preliminary experiments for the purification of rice bran galactolipase with palmitoylated gauze

Effects of $p H$ on the adsorption of galactolipase to palmitoylated gauze. It has been reported that lipase and phospholipase are well adsorbed on palmitoylated gauze at $\mathrm{pH} 7.0$ probably owing to hydrophobic interactions. ${ }^{13}$ ) In this connection, the effect of $\mathrm{pH}$ on the adsorption of galactolipase on palmitoylated gauze was examined. The results are shown in Fig. 1. The amount of the galactolipase adsorbed was markedly influenced by $\mathrm{pH}$. The maximum adsorption was attained at about pH 5.5, where $95 \%$ or more of the galactolipase was adsorbed on palmitoylated gauze.

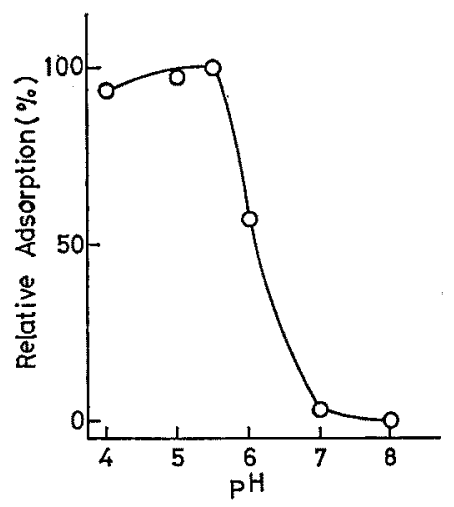

FIG. 1. Effects of $\mathrm{pH}$ on the Adsorption of Rice Bran Galactolipase to Palmitoylated Gauze.

One $\mathrm{ml}$ of rice bran crude extract $(20 \mathrm{mg}$ of protein) was loaded on a palmitoylated gauze column $(1 \times 7 \mathrm{~cm})$ previously equilibrated with $5 \mathrm{~mm}$ phosphate buffer of various $\mathrm{pH}$. The charged column was washed with $10 \mathrm{ml}$ of the same buffer, and the remaining enzyme proteins on the washed column were eluted with $10 \mathrm{ml}$ of $50 \mathrm{~mm}$ phosphate buffer ( $\mathrm{pH} 8.0$ ) containing $1 \mathrm{~mm}$ sodium deoxycholate. The eluated fractions were subjected to enzyme assay. Relative adsorption was expressed as a percentage of total activity of the enzyme adsorpted to palmitoylated gauze at $\mathrm{pH} 5.5$.

\section{Effects of reagents on adsorption. As Fig. 2} shows, the adsorption of the enzyme was strongly inhibited by detergents such as sodium deoxycholate and Triton X-100, but it was not affected by $0.1 \mathrm{M} \mathrm{NaCl}$ and $\mathrm{CaCl}_{2}$.

Effects of $\mathrm{pH}$ and detergents on elution. It was possible to elute the enzyme readily from palmitoylated gauze with $50 \mathrm{~mm}$ phosphate buffer containing sodium deoxycholate or Triton $\mathrm{X}-100$ at $\mathrm{pH} 8.0$ rather than at $\mathrm{pH} 5.5$, as shown in Fig. 3. Triton $\mathrm{X}-100$, however, 


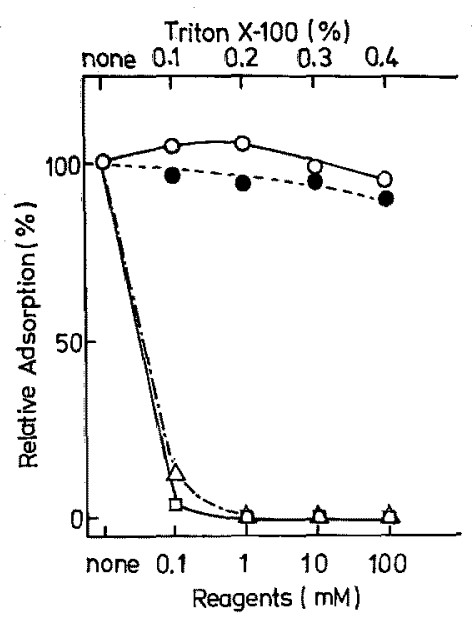

Ftg. 2. Effects of Reagents on the Adsorption of Galactolipase.

Palmitoylated gauze columns equilibrated previously with $5 \mathrm{~mm}$ phosphate buffer ( $\mathrm{pH} 5.5$ ) containing the reagents of various concentrations were used. The charged column was washed with $10 \mathrm{ml}$ of the same buffer used for equilibration, and then the remaining enzyme proteins were eluted with $10 \mathrm{ml}$ of $50 \mathrm{~mm}$ phosphate buffer ( $\mathrm{pH} 8.0$ ) containing $1 \mathrm{~mm}$ sodium deoxycholate. The eluted fractions were dialyzed to remove the excess reagents and were subjected to enzyme assay. The other conditions were similar to those described in Fig. 1.

Relative adsorptions were expressed as a percentage of total activity of the enzyme adsorbed at the same condition without the reagents.

$\Delta^{-\cdot-\triangle}$, sodium deoxycholate; $\square-\square$, Triton $\mathrm{X}-100$; $\mathrm{O}-\mathrm{O}, \mathrm{CaCl}_{2} ; \mathrm{O}-\mathrm{NaCl}$.

inhibited the enzyme activity, while sodium deoxycholate stimulated the activity (Table II). It is known that the substrate solution dispersed with sodium deoxycholate has the negative charges on the surface of the substrate micelles, whereas it dispersed with Triton $\mathrm{X}-100$ does not have such charges. It seems likely that the negative charges on the surface of the micelles stimulate the enzymic activity as the activation of Penicillium natatum phospholipase B demonstrated by Dawson. ${ }^{21)}$ Therefore, sodium deoxycholate was well suited both for emulsifying the substrate and for the elution of the enzyme from the column. In the present work, the enzyme was eluted with $50 \mathrm{~mm}$ phosphate buffer ( $\mathrm{pH} 8.0$ ) containing $1 \mathrm{mM}$ sodium

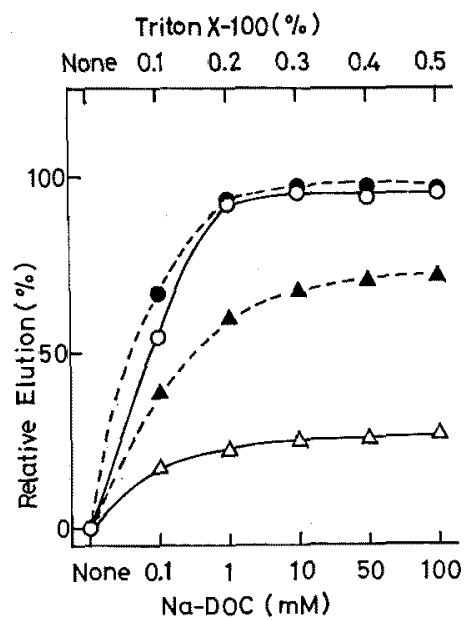

FIG. 3. Effects of pH and Detergents on Elution of Rice Bran Galactolipase from Palmitoylated Gauze.

The enzyme protein adsorbed at $\mathrm{pH} 5.5$ on palmitoylated gauze column was eluted with $10 \mathrm{ml}$ of $50 \mathrm{~mm}$ phosphate buffer (pH 5.5 and 8.0) containing the detergents of various concentrations. The eluted fractions were dialyzed to remove the detergents and then subjected to enzyme assay. The other conditions were similar to those described in Fig. 1.

O-- O, pH 8.0; sodium deoxycholate; -..., pH 8,0; Triton $\mathrm{X}-100 ; \Delta-\Delta, \mathrm{pH} 5.5$; sodium deoxycholate; $\Delta--\Delta$, pH 5.5; Triton X-100.

deoxycholate, thereby the enzyme activity retained could be released completely.

\section{Purification of rice bran galactolipase}

Unless otherwise described, all purification steps were performed at about $4^{\circ} \mathrm{C}$.

Extraction. The enzyme was extracted by the method described previously. ${ }^{97}$ Fresh rice bran prepared from brown rice was immediately defatted five times with petroleum ether at $-20^{\circ} \mathrm{C}$. The resulting defatted rice bran was homogenized with $5 \mathrm{~mm}$ Tris- $\mathrm{HCl}$ buffer ( $\mathrm{pH} 8.0$ ) in a waring blender. The homogenate was filtered through nylon cloth, and the turbid filtrate was centrifuged at $15,000 \times 9$ for $30 \mathrm{~min}$. The enzyme was further extracted from the pellets twice by the same method. The combined supernatant was concentrated by freeze-drying and the preparation obtained was designated as "a crude extract."

Affinity chromatography on palmitoylated gauze. The crude extract was dialyzed against 
$5 \mathrm{~mm}$ phosphate buffer (pH 5.5) for $24 \mathrm{hr}$, and the dialyzate was applied to a palmitoylated gauze column $(3 \times 20 \mathrm{~cm})$ equilibrated previously with the same buffer. The charged column was washed with the same buffer, and then the adsorbed enzyme was eluted with $50 \mathrm{~mm}$ phosphate buffer ( $\mathrm{pH} 8.0$ ) containing $1 \mathrm{~mm}$ sodium deoxycholate. As Fig. 4 shows, galactolipase was found in the adsorbed fractions, and could be well separated from other proteins. The active fractions were collected, dialyzed for $24 \mathrm{hr}$ against $5 \mathrm{~mm}$ phosphate buffer $(\mathrm{pH}$ 8.0 ), and then concentrated by freeze-drying. The enzyme obtained was purified about 150fold over the crude extract with a yield of $91 \%$. The ratio of the specific activity of galactolipase to that of lipase in the crude extract (about 6:10) was changed to about $100: 0.1$ by the gauze column.

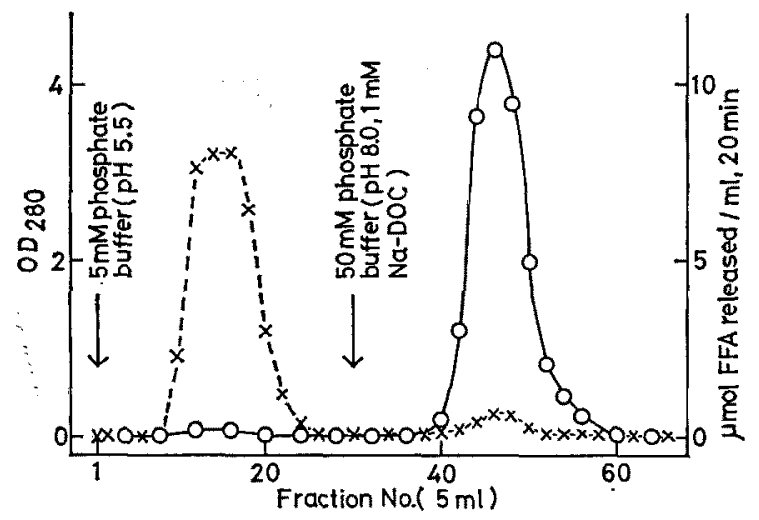

FIG. 4. Affinity Chromatography of Rice Bran Crude Extract on a Palmitoylated Gauze Column.

Rice bran crude extract (220 mg of protein) was loaded on a palmitoylated gauze column $(3 \times 20 \mathrm{~cm})$ previously equilibrated with $5 \mathrm{~mm}$ phosphate buffer (pH 5.5), and then the remaining enzyme proteins on the washed column were eluted with $50 \mathrm{~mm}$ phosphate buffer ( $\mathrm{pH} 8.0$ ) containing $1 \mathrm{~mm}$ sodium deoxycholate. The fractions of $5 \mathrm{ml}$ were collected and subjected to enzyme assay.

$\bigcirc-0$, galactolipase activity; $\times-\cdots \times$, optical density at $280 \mathrm{~nm}$.

Gel filtration on a Sephadex G-100 column. The enzyme preparation obtained by affinity chromatography was loaded on a Sephadex G-100 column $(3 \times 40 \mathrm{~cm})$ equilibrated with
$5 \mathrm{~mm}$ phosphate buffer ( $\mathrm{pH} \mathrm{8.0)}$ and was eluted with the same buffer. The elution pattern of the galactolipase activity gave a single peak, as shown in Fig. 5. The active fractions (fraction Nos. $32 \sim 40$ ) were combined, concentrated by freeze-drying, and dialyzed against $5 \mathrm{~mm}$ phosphate buffer ( $\mathrm{pH} 8.0$ ) for $12 \mathrm{hr}$.

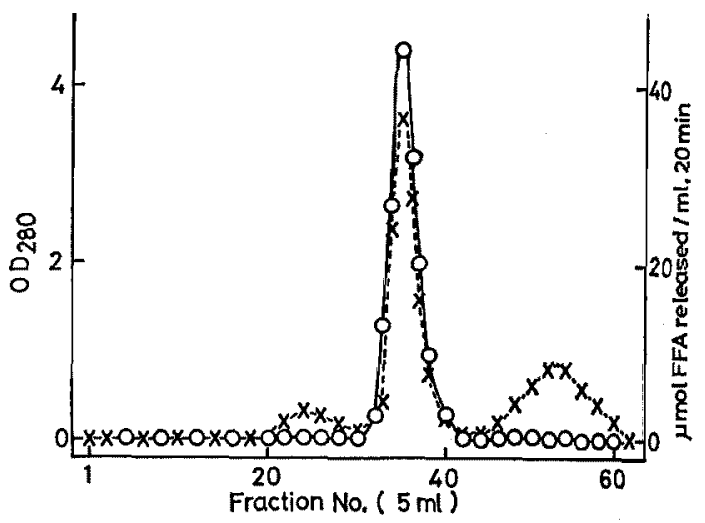

FIG. 5. Gel Filtration of Rice Bran Galactolipase on a Sephadex G-100 Column.

The enzyme fraction (170 $\mathrm{mg}$ of protein) obtained by affinity chromatography was loaded on a Sephadex G-100 column $(3 \times 40 \mathrm{~cm})$ equilibrated with $5 \mathrm{~mm}$ phosphate buffer ( $\mathrm{pH} 8.0$ ). The fractions were collected and subjected to enzyme assay.

$\bigcirc-O$, galactolipase activity; $\times \ldots \ldots \times$, optical density at $280 \mathrm{~nm}$.

Isoelectric focusing. The resulting dialyzate was subjected to isoelectric focusing. As Fig. 6 shows, the enzyme activity was separated into four peaks $(\mathrm{G}-1,2,3$, and 4$)$, their isoelectric points being $\mathrm{pH} 9.6,7.3,4.9$, and 3.5 , respectively. The combined fractions of Nos. $3 \sim 7$ (peak G-1), Nos. $9 \sim 14$ (peak G-2), Nos. 19 25 (peak G-3), and Nos. 27 34 (peak G-4) gave the yields of the enzyme activity of $19,57,9$, and $7 \%$, respectively, of the total activity applied to the column. In this experiment, the major peak (G-2) with pI 7.3, one of them, was investigated as "a purified galactolipase." The steps of the purification procedure and the yield of enzyme at each step are summarized in Table I. About $45 \mathrm{mg}$ of the purified enzyme was isolated from $800 \mathrm{~g}$ of the fresh defatted rice bran. The enzyme was purified 268-fold in a yield of about $40 \%$. 
Table I. Purification of Galactolipase from Rice Bran

\begin{tabular}{lccccc}
\hline Stages & $\begin{array}{c}\text { Total } \\
\text { protein } \\
(\mathrm{mg})\end{array}$ & $\begin{array}{c}\text { Total } \\
\text { activity } \\
(\mathrm{U})\end{array}$ & $\begin{array}{c}\text { Specific } \\
\text { activity } \\
(\mathrm{mU} / \mathrm{mg})\end{array}$ & $\begin{array}{c}\text { Purifi- } \\
\text { cation } \\
\text { (-fold) }\end{array}$ & $\begin{array}{c}\text { Over-all } \\
\text { yield } \\
(\%)\end{array}$ \\
\hline Crude extract & 30,160 & 412 & 14 & 1 & 100 \\
Palmitoylated gauze column & 181 & 372 & 2055 & 147 & 91 \\
Sephadex G-100 & 98 & 308 & 3156 & 225 & 75 \\
Isoelectric focusing (G-2 fraction) & 44.8 & 168 & 3750 & 268 & 41 \\
\hline
\end{tabular}

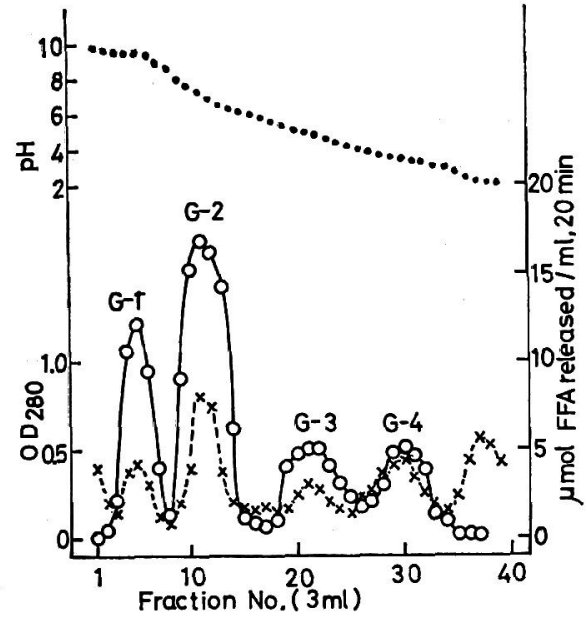

FIG. 6. Isoelectric Focusing of Rice Bran Galactolipase.

The enzyme fraction ( $41 \mathrm{mg}$ of protein) obtained by gel filtration was subjected to isoelectric focusing. Isoelectric focusing was carried out for $48 \mathrm{hr}$ at $900 \mathrm{~V}$ and $4^{\circ} \mathrm{C}$ in a LKB 8101 column using ampholyte for the $\mathrm{pH}$ range of $3.5 \sim 10$ with the cathode at the bottom. After electrophoresis, the content of the column was fractionated into $3 \mathrm{ml}$ portions. Each fraction was assayed for $\mathrm{pH}$, optical density at $280 \mathrm{~nm}$, and the enzymic activity.

----., pH; $\times---\times$, optical density at $280 \mathrm{~nm} ; \mathrm{O}-\mathrm{O}$, galactolipase activity.

Homogeneity of enzyme protein. The homogeneity of the purified enzyme preparation was substantiated by polyacrylamide gel disc electrophoresis, as well as by isoelectric focusing and gel filtration on Sephadex G-100. As Fig. 7 shows, the purified enzyme gave a single protein band on polyacrylamide gel disc electrophoresis. Furthermore, both isoelectric focusing and gel filtration of the purified enzyme preparation (G-2) also gave a single protein peak coinciding with the enzymic activity.

The purified enzyme hydrolyzed rapidly

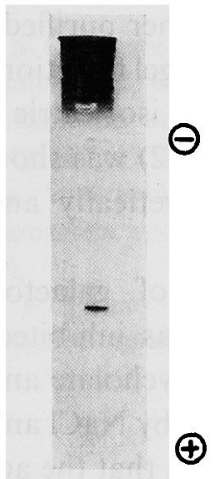

Fig. 7. Disc Electrophoresis of the Purified Rice Bran Galactolipase.

The purified rice bran galactolipase was subjected to disc electrophoresis in $7 \%$ polyacrylamide gel. Electrophoresis was carried out at a constant current of $3 \mathrm{~mA}$ per gel for $3 \mathrm{hr}$.

TABLE II. HYDROLYSIS RATES FOR LIPIDS

The incubation mixtures contained $0.5 \mu \mathrm{mol}$ of a substrate and $1 \mu \mathrm{mol}$ of sodium deoxycholate (for monogalactolipid and phosphatidylcholine), or $10 \mu \mathrm{mol}$ of long-chain triacylglycerol and $2 \mu \mathrm{mol}$ of sodium deoxycholate (for triacylglycerol) and $0.2 \mathrm{ml}$ of $0.5 \mathrm{M}$ Tris- $\mathrm{HCl}$ buffer $(\mathrm{pH} 7.5,8.0$ and 9.0 for galactolipid, phospholipid and triacylglycerol, respectively). Total volume, $1 \mathrm{ml}$; incubation at $35^{\circ} \mathrm{C}$ for $20 \mathrm{~min}$. Hydrolysis rates were expressed as a percentage of the rate of monogalactosyldiacylglycerol.

\begin{tabular}{lc}
\hline \multicolumn{1}{c}{ Substrates } & Hydrolysis rates $(\%)$ \\
\hline Monogalactosyldiacylglycerol & 100 \\
Phosphatidylcholine & 27 \\
Triacylglycerol & trace \\
\hline
\end{tabular}

monogalactosyldiacylglycerol, and also slowly phosphatidylcholine, but hardly long chain triacylglycerol, as Table II shows.

\section{DISCUSSION}

Previously, the authors partially purified a galactolipase from rice bran and examined its properties. ${ }^{91}$ However, further purification of 
the enzyme by means of DEAE- and CMSephadex ion exchange chromatographies was unsuccessful, because of the lability of the enzyme, and the enzyme preparation was not completely separated from lipase activity. ${ }^{9 !}$ In this work, galactolipase was separated from other (non-enzymatic) proteins by means of affinity chromatography on palmitoylated gauze, and was further purified about 270 -fold in a yield of $40 \%$ by gel filtration on a Sephadex G-100 column and isoelectric focusing. The purified enzyme ( $G-2)$ was shown to be homogeneous electrophoretically and rarely to involve lipase activity.

The adsorption of galactolipase on palmitoylated gauze was inhibited by detergents such as sodium deoxycholate and Triton X-100 but was not affected by $\mathrm{NaCl}$ and $\mathrm{CaCl}_{2}$ (Fig.2). These results suggest that the adsorption is due to hydrophobic interactions rather than electrostatic forces between the substrate and the enzyme as pointed out by Horiuti et al. ${ }^{13}$ and Lairon et al. ${ }^{12)}$ However, the adsorption of the enzyme was markedly influenced by $\mathrm{pH}$ (Fig. 1). Such an effect was also found in the affinity chromatography of other galactolipases in higher plants such as Phaseolus vulgaris leaves ${ }^{22}$ and potato leaves. ${ }^{23}$ ) It seems that the adsorption of these galactolipases on palmitoylated gauze is also dependent on the conformation of the enzyme proteins. Both galactolipase and lipase were adsorbed on the column, but only the former was eluted under the condition used in this experiment. Therefore, palmitoylated gauze is useful for the purification of galactolipases from other sources. Similar results with respect to affinity chromatography have been reported with agarose derivatives $^{24 \sim 29}$ and with $p$-cellulose..$^{30}$

The purified enzyme rarely catalyze the hydrolysis of long-chain triacylglycerol, so that the galactolipase was well separated from lipase activity. However, it clearly exhibited phospholipase activity, too (Table II). The enzyme was found to be a single protein electrophoretically (Fig. 7). In addition, galactolipase and phospholipase activities were not separated from each other throughout all purification procedures examined. These results suggest that a single enzyme exhibits not only galactolipase but also phospholipase activities as the purified lipolytic acyl-hydrolase from potato tubers does. ${ }^{\theta}$ ( Consequently, the purified rice bran galactolipase may belong to a non-specific acyl-hydrolase. The structure and nature of such an enzyme are very interesting and will be reported in near future.

After isoelectric focusing, galactolipase was separated into four peaks with different isoelectric points (Fig. 6). Since the four galactolipases were present even in the crude extract from brown rice, ${ }^{9}$ they would not be so-called artifacts. The enzymatic relationship among these enzymes is yet not clear. However, it seems that galactolipase in rice bran exists in multiple forms similar to those of rice bran lipase previously described..$^{9,31}$

Acknowledgement. This work was supported in part by a Scientific Research Grant from the Ministry of Education of Japan. The authors wish to thank Mr. Yukio Takami and Mr. Hideo Nitta, Central Agricultural Experiment Station of Shimane Prefecture, for the kind supply of rice grains, and the Laboratory of Crop Science, Faculty of Agriculture, Shimane University, for the preparation of rice bran.

\section{REFERENCES}

1) P. S. Sastry and M. Kates, Biochemistry, 13, 1280 (1964).

2) P. J. Helmsing, Biochim. Biophys. Acta, 144, 470 (1967).

3) P. J. Helmsing, ibid., 178, 519 (1969).

4) M. M. Anderson, R. E. McCarty and E. Zimmer, Plant Physiol., 53, 699 (1974).

5) T. Galliard, Biochem. J., 121, 379 (1971).

6) O. Hirayama, H. Matsuda, H. Takeda, K. Maenaka and H. Takatsuka, Biochim. Biophys. Acta, 384, 127 (1975).

7) T. Galliard, "Recent Advances in the Chemistry and Biochemistry of Plant Lipids," ed. by T. Galliard and E. L. Mercer, Academic Press Inc., New York, 1975, p. 319.

8) H. Matsuda and O. Hirayama, Nippon Nồgeikagaku Kaishi, 47, 379 (1973).

9) O. Hirayama and H. Matsuda, ibid., 49, 569 (1975).

10) C. Q. Rock and F. Snyder, J. Biol. Chem., 250, 6564 (1976).

11) A. Verine, H. Giudicelli and J. Boyer, Biochim. 
Biophys. Acta, 469, 125 (1974).

12) D. Lairon, G. Nalbone, H. Lafont, J. Leonard, N. Domingo, J. C. H. Hauton and R. Verger, Biochemistry, 17, 205 (1978).

13) Y. Horiuti and S. Imamura, J. Biochem., 81, 1639 (1977).

14) O. Hirayama, ibid., 57, 581 (1965).

15) M. C. Pangborn, J. Biol. Chem., 188, 471 (1951).

16) K. K. Carroll and B. Serdarevich, "Lipid Chromatographic Analysis," Vol. 1, ed. by G. V. Marinetti, Dekker, Inc., New York, 1967, p. 205.

17) O. Hirayama and H. Matsuda, Agric. Biol. Chem., 36, 1831 (1972).

18) E. F. Hartree, Anal. Biochem., 48, 422 (1972).

19) L. Ornstein, Ann. N. Y. Acad. Sci., 121, 321 (1964).

20) B. J. Davis, ibid., 121, 404 (1964).

21) R. M. C. Dawson, Biochem. J., 68, 352 (1958); 70, 559 (1958).

22) H. Matsuda and O. Hirayama, Agric. Biol. Chem., 43, 563 (1979).

23) H. Matsuda and O. Hirayama, Biochim. Biophys.
Acta, in press.

24) A. Wichman and L. O. Anderson, ibid., 372, 218 (1974).

25) H. P. Jennissen and L. M. G. Heilmeyer Jr., Biochemistry, 14, 754 (1975).

26) W. Nieuwenhuizn, F. C. Reman, I. A. M. Vermeer and T. Vermond, Biochim. Biophys. Acta. 431, 288 (1976).

27) Y. Kosugi and H. Suzuki, J. Lipid Res., 17, 307 (1976).

28) C. R. Geren, S. C. Magee and K. E. Ebner, Arch. Biochem. Biophys., 172, 149 (1976).

29) J. Sekiya, T. Kajiwara and A. Hatanaka, Agric. Biol. Chem., 42, 677 (1978).

30) I. Takagahara, Y. Suzuki, T. Fujita, J. Yamauti, K. Fuji, J. Yamashita and T. Horio, J. Biochem., 83, 585 (1978).

31) M. Funatsu, Y. Aizono, K. Hayashi, M. Watanabe and M. Eto, Agric. Biol. Chem., 35, 734 (1971). 